\title{
Automata: from Magic to Science and Back Again
}

\author{
Nikolai Molok \\ Department of Fine Arts and Architecture \\ State Institute for Art Studies \\ Moscow, Russia \\ E-mail: nmolok@gmail.com
}

\begin{abstract}
The article considers a broad range of eighteenth-century art and culture phenomena that were responsible for the birth of Frankenstein, the great romantic monster. These include popular optical effects, such as the "magic lantern" and phantasmagoria, that filled the enlightened public with awe by the visual demonstration of spirits and the "resurrection of the dead"; galvanism and anatomical experiments in bringing the dead back to life with the help of electricity; enthusiastic invention of moving automatons that imitated the behavior and skills of living creatures and, last but not least, androids as the direct prototypes of the future monster. Shifting gradually from the outposts of scientific experiment to the sphere of entertainment culture, all these phenomena happened to be immediately related to the mythology of creating the ideal human being that, at the will of its creator - the scholarly magus - turned out to be the first monster in culture history.
\end{abstract}

Keywords-automata; Frankenstein; monsters; "magic lantern"; phantasmagoria; galvanism; moving anatomy; automaton; android

\section{INTRODUCTION}

Two of the greatest anti-heroes of the modern age - the monster created by the doctor Victor Frankenstein and the first vampire, Lord Ruthven - were born on the same day in June 1816. Lord byron and a group of friends were gathered at the Villa Diodati beside Lake Geneva. The weather was bad $^{1}$, so to entertain themselves the company read Fantasmagoriana, a collection of tales about spirits and ghosts, and this it was that gave rise to the idea of writing their own 'horror stories'. One of those stories was to be Frankenstein: or, The Modern Prometheus, by Mary Shelley, published in 1818; the other was John Polidori's The Vampyre (1819). In both books the main heroes were literally raised from the dead. But if the resurrection (or, to use Bram Stoker's term, 'un-death') of Lord Ruthven, as of all the vampires who followed after, was brought about by supernatural means (magic), Frankenstein's monster was the creation of a scholar, doctor, philosopher and engineer.

Through Professor Waldman (Frankenstein's teacher), Mary Shelley sang the praises of learned men 'whose hands

In April 1815 there was an eruption of Mount Tambora in Indonesia, which led to climate change across the world, including in Europe. The weather in Switzerland was particularly cold over the summer of 1816 , when snow fell regularly. seem only made to dabble in dirt, and their eyes to pore over the microscope or crucible' but who 'have indeed performed miracles': 'They penetrate into the recesses of nature, and show how she works in her hiding places. They ascend into the heavens: they have discovered how the blood circulates, and the nature of the air we breathe. They have acquired new and almost unlimited powers; they can command the thunders of heaven, mimic the earthquake, and even mock the invisible world with its own shadows' (Frankenstein Chapter II).

Frankenstein saw himself not so much as a scientist, however, as a demiurge endowed with divine power: 'After days and nights of incredible labour and fatigue, I succeeded in discovering the cause of generation and life; nay, more, I became myself capable of bestowing animation upon lifeless matter... I found [an] astonishing a power placed within my hands...' (Frankenstein, Chapter III).

Created in Frankenstein's 'factory for genetic engineering' [1], the monster was not merely human-like but a cyborg, a man-machine. And as with a machine he had no name: known simply as 'Frankenstein's monster', he belonged to his creator and master, like 'a Ford worker',

On the one hand the image of Frankenstein's monster reflects the Romantics' interest in horror, in 'techno-Gothic' [2] and the psychology of the human spirit. On the other, however, it marks an unusual culmination to those experiments in returning the dead to life and in creating an artificial human to which the eighteenth century had devoted so much effort.

\section{PHANTASMAGORIA}

It is not difficult to trace the eighteenth-century roots of Frankenstein's monster.

\footnotetext{
On Frankenstein's monster and vampires as the product of modernity and as metaphorical expressions of fear in the face of bourgeois civilisation see the post-Fordian interpretation of Shelley and Stoker's novels put forward byFranco Moretti, 'The Dialectic of Fear', New Left Review 136, 1982: 67-85. It was only at the end of the nineteenth century (1886) that any monster created by a scientist was given a name: Mr Hyde. It was a decade later, in 1897, that Count Dracula replaced Lord Ruthven in the pantheon of anti-heroes.
} 
Our first hint comes in the very title of the book read by those gathered at the Villa Diodati, Fantasmagoriana ${ }^{3}$. Its title refers to one of the eighteenth century's most popular spectacles, the phantasmagoria (fantasmagoria; a series of dream-like images). In the phantasmagoria pictures were 'brought to life' with the aid of a magic lantern (laterna magica, or lucerna magica in the words of Athanasius Kircher).

The magic lantern (also sometimes called 'the lantern of fear') was frightening for two reasons. Firstly, spectators could not understand the principles underlying its workings, so they thought the effect was created using (black) magic. Secondly, the choice of images was chosen for frightening effect: in the sixteenth and seventeenth centuries magic lanterns were used as an instrument of Jesuit doctrine, for propagandising faith (propagatio fidei), and so the figures they 'brought to life' were devils, such scenes being intended to inspire viewers to live a life of righteousness. This function as a magical instrument to instil fear was described in a definition of 'magic lantern' published in the late seventeenth century: 'a little optical machine that makes one see, on a white wall in the darkness, various spectres and monsters so awful that those who do not know the secret think that it is done by magic' ${ }^{4}$.

Yet the inventors and researchers of the magic lantern, Christiaan Huygens, Thomas Rasmussen Walgensten, Athantasius Kircher, Gaspar Schott and others, saw it not in the context of black magic but of 'optical magic' or, more broadly, 'mathematical magic'. much a 'philosophical instrument' as the microscope or the telescope.

Later Enlightenment encyclopaedias retained the word magic only in the name, magic lantern. For Chambers the 'Magic Lanthorn' was 'an optic machine, by means whereof little painted images are represented on an opposite wall of a dark room, magnified to any bigness at pleasure'[3]. For Diderot and d'Alembert it was 'a machine... which has the property of making appear large upon a white wall figures of small size painted in transparent colours on pieces of thin glass' ${ }^{\prime 6}$.

Fantasmagoriana, ou Recueil d'histoires d'apparitions des spectres, revenans, famtômes, etc., Paris: F. Schoell, 1812. This was a French translation by Jean-Baptiste Benoît Eyriès of the German Gespensterbuch [Book of Ghosts] compiled by Johann August Apel and Friedrich Laun, the first volume of which had appeared in 1811.

'une petite machine d'Optique, qui fait voir dans l'obscurité sur une muraille blanche plusieurs spectres \& monstres si affreux, que celuy qui n'en sçait pas le secret, croit que cela le fait par magie.' Antoine Furetière, Essais d'un dictionnaire universel, [Paris], 1684: 'Lanterne magique' [s.p.]

On Kircher and 'optical magic' in the sixteenth and seventeenth centuries see: Stuart Clark, Vanities of the Eye: Vision in Early Modern European Culture, Oxford-New York: Oxford University Press, 2007, Chapter 3: 'Prestiges. Illusions in Magic and Art': 78-122. See also: Anthony Grafton, Magic and Technology in Early Modern Europe, Washington: Smithsonian Institution Libraries, 2005.

'Lanterne magique: machine... laquelle a la propriété de faire paroître en grand sur une muraille blanche des figures peintes en petit sur des morceaux de verre minces, \& avec des couleurs bien transparentes.'
By the middle of the eighteenth century, then, the magic lantern was no longer frightening. It had become a scientific toy to be added to the repertoire of physical and mathematical recreations and a 'curiosity' to be found in everyday life as one 'le arti per via' (street entertainments): magic lanterns simply replaced the Savoyard's marmot.

But the phantasmagoria spectacles returned the magic lantern to the world of horror: once again the principles behind them were unclear, since unlike Savoyards who displayed their 'curiosity' to the public the lanterns were not made visible and the spectator saw only the projection created. As before, the pictures 'brought to life' showed the devil.

Not surprisingly, therefore, we can see how the phantasmagoria existed in the context of the Freemasons, with their interest in mysteries, semi-scientific experimentation and light effects. In the 1760s Johann Georg Schröpfer, an occultist and illusionist, turned his coffee-shop in Leipzig into a masonic lodge, with a room for séances where he organised light shows accompanied by sound effects, smoke and smells and electrical charges. That room was adorned with skulls and allegorical depictions of Death. Schröpfer himself summoned up the spirits.

It was as 'Schröpfer's ghost appearances' (Schröpferische Geister Erscheinungen) that Paul Philidor's shows were first presented in 1790 in Berlin and Vienna. The German physicist perfected the technique, introducing the Argand lamp, brighter than candles or oil lamps, and setting his magic lantern on wheels, allowing him to enlarge or reduce the image and thus create the illusion of movement. Thanks to this it became possible to show his 'living pictures' on large screens and in bigger spaces to a larger audience.

Such phantasmagorias, during which 'spirits appeared', soon came to be widespread, particularly in Germany, and became an independent genre within not only masonic but popular culture, or, as Étienne-Gaspard Robertson put it, 'a new kind of exhibition ${ }^{\text {,7 }}$. In 1790 the mason and scholar Karl von Eckartshausen, author of the treatise Aufschlüsse über Magie (Explanations concerning Magic), put forward the idea of a 'pocket magic lantern with a built-in cooling system to prevent the supposed necromancer's clothes from going up flames'. This could be used to frighten 'an unsuspecting companion on an evening stroll' [4]. In 1796 a law was introduced in Prussia that imposed a prison sentence of between six months and two years for 'fraud by means of ostensible or false magic' [5].

In 1792-1793 Philidor's show was presented in Paris, now under the title 'phantasmagoria', and it was there that it was seen by the Belgian physicist and future aeronaut (remember Shelley's 'they ascend into the heavens') Étienne-Gaspard Robertson. Taking up Philidor's

Encyclopédie ou Dictionnaire raisonné des sciences, des arts et des métiers, IX, Paris: Briasson, David etc, 1765, p. 276.

'Ce genre si nouveau d'exhibition.' Étienne-Gaspard Robertson (Robert), Mémoires récréatifs, scientifiques et anecdotiques, 2 vols, Paris: Chez l'auteur, 1831-33, I, p. 206. 
phantasmagoria technique and his repertoire (like Philidor, for instance, Robertson ended his spectacles with an image of a devil or skull), in 1798 he set up his own show in Paris, which was to go on to become one of the most famous in all history. It continued in the French capital for six years and then he took the show on the road, taking it through Europe and even reaching Moscow and St Petersburg ${ }^{8}$. To avoid accusations of plagiarism (and of course to capture the patriotic spirit of the age!) he changed the Latinised version of the name to the French form, fantasmagorie. It was thus that the term featured in Mercier's dictionary of neologisms in 1801: 'Optical trick which makes one see all the multiple fine battles between shadow and light, which at the same time reveals old priestly deceits. These phantoms, created at will, moving, these false apparitions, amuse the vulgar and prompt the philosopher to dream, ${ }^{, 9}$.

Robertson's phantasmagoria was perfect in this sense [6]. He had everything carefully worked out, from the very entrance. His séances took place in an abandoned Capuchin monastery, which he had made look more 'Gothic', clearly to recall the Capuchin monastery in Matthew Lewis' novel The Monk (then extremely popular not only in England but in France, where a translation had been published in 1797). Spectators had to pass through the cemetery before entering a corridor with Egyptian hieroglyphics and 'sepulchral' illumination 'seeming to announce one's entry into the mysteries of Isis', then they looked on as various physical experiments were conducted, including experiments in hydraulics and galvanism (sic!), they talked with an 'invisible woman' (the voice came from a glass sphere suspended from the ceiling), and only at the end of this path - which was something like a ritual of initiation - did they find themselves in the room where they would see the phantasmagoria itself. Amidst pitch darkness (the walls were all draped with black fabric), rays of light flashed out suddenly, their source unseen by the spectator. The rays of the fantascope, as Robertson called his modified magic lantern, pierced through clouds of smoke and projected the image onto a cambric curtain, but that too was unseen by the viewers and so it seemed to them that what they saw had emerged from the darkness. The fantascope could be moved and thus the image moved too, and often Robertson used several lamps at once, so that the images were multiplied. His show incorporated sound (thunderclaps) and musical effects (bells ringing, Franklin's glass harmonica).

Before the start of the spectacle, Robertson spoke to his audience: 'The purpose of the phantasmagoria is to familiarise you with extraordinary objects: I have offered

\footnotetext{
8 He devoted the second volume of his memoirs to his time in
} Russia; Robertson, Op. cit., II. See: Tatiana Smoliarova, 'Взлет как взгляд, или Бельгиец в русском небе' [Flight as Gaze, or A Belgian in the Russian Sky], Новое литературное обозрение [New Literary Review] 76, 2005. Available online: http://magazines.russ.ru/nlo/2005/76/smo11.html.

'Jeu d'optique qui fait voir tous les combats multipliés et fins de l'ombre et de la lumière, et qui révèle en même temps d'anciennes fourberies de prêtres. Ces fantômes créés à volonté, et mouvans, ces fausses apparences amusent le vulgaire, et font rêver le philosophe.' LouisSébastien Mercier, Néologie ou Vocabulaire de mots nouveaux. I, Paris: Moussard, 1801, p. 259. you ghosts, now I shall summon up shades you know, ${ }^{10}$. And indeed, in the wake of the Three Graces turning into skeletons, Macbeth's witches, the head of the Gorgon Medusa rolling its eyes and scenes of the temptation of St Anthony or the Bloody Nun (again Lewis' The Monk), spectators could see French revolutionaries who had been executed, the biggest hit being Robespierre, who arose from his tomb only to be turned to dust...

Complete darkness, atmospheric music, smoke, light projections of which the source was invisible to the spectator, all came together to create a situation in which the viewer's own perceptions could be controlled. The phantasmagoria was so lifelike that viewers leaped back in horror, thinking they were seeing real ghosts. This becomes clear not only from contemporary prints (not least the frontispiece to Robertson's memoirs), although they were of course in part intended as advertisements, but from the reminiscences of educated eyewitnesses. David Brewster, no less, the physicist who invented the kaleidoscope, attended Philipsthal's show in London in 1802 and described what he saw: 'The spectators were not only surprised but agitated, and many of them were of opinion that they could have touched the figures' [7]. And of course the ghosts born of the phantasmagoria were to become the object of desire: in Schiller's novella Der Geisterseher: Aus den Papieren des Grafen von $\mathrm{O}^{* *}$ (The Ghost-Seer: From the Papers of Count of $\left.\mathrm{O}^{* *} ; 1787-1789\right)$ the main hero, Prince Alexander, sees the phantasmagoria (having been given an electric shock during a séance, a technique employed by Philidor in his show and later used by Dr Frankenstein) and falls in love with an 'image', a picture that turns into a ghost and is then transformed into a beautiful unknown woman.

Robertson's most scandalous demonstration took place on 28 March 1798, a famous 'spiritualist séance' during which the 'sorcerer' summoned up the spirits of individuals named by people present [8]. One of the guests asked to speak to a woman he had loved and showed Robertson a portrait miniature of her; then, when she appeared in the light of the fantascope, another man declared, 'Heavens! I think I see my wife!'11 A Swiss patriot wanted to 'meet' William Tell, the Abbot Delille (a poet) asked for Virgil, while the author of a number of plays requested Voltaire. Lastly, at the very end, a pardoned royalist asked that he bring back Louis XVI, but Robertson, fearing reprisals, cleverly refused.

Despite his caution, the secret police decided that Robertson might indeed have the power to resurrect Louis XVI (!) and temporarily closed the show.

\section{GALVANISM}

Perhaps those fears on the part of the secret police were not without foundation, for in the eighteenth century,

10 'Le but de la fantasmagorie est de vous familiaris er avec des objets extraordinaires; je vous ai offert des spectres, je vais actuellement faire apparaître des ombres connues.' Robertson, Op. cit., I, 282.

11 'Ciel! je crois que c'est ma femme!' Étienne-Gaspard Robertson (Robert), Recreational, scientific and anecdotal memoirs, 2 flights, Paris: In the author, 1831-33, I, p. 217. 
experiments were not limited to summoning up spirits, but also aimed to return the dead to life.

Doctors and physicists studied the human nervous system through which, according to Descartes, the soul (or brain) runs 'the human machine'. And if the individual can be controlled, then he or she can be controlled from without. The nerves can be directed. But if Franz Mesmer's magnetism was soon declared to be false science and charlatanism, the use of electricity led to more convincing (in the scientific sense), if no less amazing, results.

Luigi Galvani used a battery made of copper, zinc and acid to pass an electric current through a dead frog, which made the legs move. In 1791 he published the results of his experiments in De viribus electricitatis, a treatise on the effect of electricity on the muscles. The following year Alessandro Volta gave his first talk on 'animal electricity' (Memoria sull'elettricità animale), in which he also spoke of ways of stimulating the muscles using electricity.

Galviani's nephew, Giovanni Aldini, conducted experiments not only on animals but on people (by special dispensation of Napoleon). He was allowed to use corpses, attaching electrodes to different parts of the body, his experiments proving that one could move the muscles by acting on the nerves. In Bologna in 1802 he applied galvanic shocks to the severed heads of two criminals, which resulted in terrible facial grimaces ${ }^{12}$. Aldini himself described how he stood beside the scaffold, 'beneath the axe of the law', to get bodies straight from the executioner, before the blood had all seeped out of them [9]. Before it had been thought, when doctors used corpses, that the cells were already dead. Aldini declared them to still contain vital force.

On 18 January 1803 Aldini put on what was probably his most famous galvanic 'spectacle' in London: he decided to give life to the murdered George Foster, whose corpse he bought straight from the hanging at Newgate. When he connected wires to Foster's face in his anatomical theatre, 'the jaws of the deceased criminal began to quiver, and the adjoining muscles were horribly contorted, and one eye was actually opened... some... thought that the wretched man was on the eve of being restored to life,' recorded the Newgate Calendar [10].

Although it was originally a purely scientific practice, galvanism appealed very much to the eighteenth-century taste for the macabre and the awful, and so, just like phantasmagoria, it soon became 'a new kind of exhibition'. Galvanic shows partly usurped the place of 'the theatre of terror', as Michel Foucault described public executions: [11] during open lectures and demonstrations by Aldini, Robertson or André-Jacques Garnerin (a balloonist and the

12 Giovanni [Jean] Aldini. Essai théorique et expérimental sur le galvanisme, Paris: Fournier fils, 1804, I: 69 ff. What they must have looked like can be concluded from later photographs taken during electrophysiological experiments by Duchenne, although he was studying muscle spasms and emotional expression in the living. Guillaume Benjamin Duchenne, Mécanisme de la physionomie humaine, ou Analyse électro-physiologique de l'expression des passions, Paris: Veuve Jules Renouard, 1862. first parachutist) people were just as amazed and sometimes they were literally frightened to death ${ }^{13}$.

One of Garnerin's shows devoted to electricity, aerostatics, gases and phantasmagoria, held on 28 December 1814 - two years before that trip to Lake Geneva - was attended by Mary Shelley ${ }^{14}$. And in the foreword to the third addition of Frankenstein in 1831, she described the birth of the novel: 'During one of these [conversations between Lord Byron and Shelley], various philosophical doctrines were discussed, and among others the nature of the principle of life, and whether there was any probability of its ever being discovered and communicated. They talked of the experiments of Dr. Darwin... Perhaps a corpse would be reanimated; galvanism had given token of such things: perhaps the component parts of a creature might be manufactured, brought together, and endued with vital warmth.'

Indeed, unlike Galvani, Aldini or Garnerin, Dr Frankenstein not only brought dead matter to life but he literally assembled his monster from parts: 'I collected bones from charnel houses; and disturbed, with profane fingers, the tremendous secrets of the human frame... The dissecting room and the slaughter-house furnished many of my materials' (Frankenstein, Chapter III). Those parts, whether living or dead matter, each self-referential, unconnected among themselves, were assembled into a single whole using the 'shock technique' and were brought to life with electricity (also a shock).

\section{MOVING ANATOMY}

Frankenstein's method of assembling his monster from different parts also echoes another sphere of eighteenthcentury science, anatomical models, which were so often equipped with mechanical features.

Along with galvanism, such anatomical automata reflected the period's widespread interest in how the human body worked: are the movements of the human (or animal) organism essentially purely mechanical? 'It can be no mistake,' wrote La Mettrie in his Homme Machine (Man a Machine) of 1748, 'if I suppose the body of a man to be a clock, tho' a stupendous one...' ${ }^{15}$. All the wires and chains and springs and other bits and pieces used to set anatomical automata in motion were like the organs of the human body, the muscles and vessels and so on. Anatomical automata were intended to illustrate, study and simulate how the organism worked.

13 As the Newgate Calendar recorded (Op. cit.), Mr Pass, the beadle of the Surgeon's Company, who had been present during Aldini's experiment on Foster's corpse, 'was so alarmed that he died of fright soon after his return home'.

14 Recorded in her journal. Garnerin's show in London was entitled Theatre of Grand Philosophical Recreations. Fascinatingly, the advertisement for Garnerin's next show on 19 January 1815 added to the standard range of 'recreations' an experiment to resurrect Joanna Southcott, a well-known prophetess who had died three weeks previously.

15 'Je ne me trompe point; le corps humain est une horloge, mais immense...' Julien Offray de La Mettrie, L'homme machine, Leyden: Elie Luzac, fils, 1748: 92; English edn Man a Machine, Dublin: W. Brien, 1749, p. 62 . 
From this point of view, therefore, the life-sized duck of Jacques de Vaucanson (1730s), becomes particularly interesting. It could quack and move, drink water, peck at grain, digest it and defecate. Holes in its copper body allowed the viewer to see all the 'physiological' processes in action. Vaucanson's plans included the creation of an automaton that would show the circulation of the blood and breathing. He proposed that his automata - which he called anatomie mouvante (moving anatomy) - be used as an aid to medical training ('Inspection of the machine will give a better understanding of the imitation of nature than a longer description, which would be too like an anatomical explanation, ${ }^{16}$ ). In order to make them more life-like and to make their workings clearer, Vaucanson used rubber, then a very new material.

'Moving anatomies' aroused the interest of mechanics, but also of doctors, notably the surgeons François Quesnay and Claude-Nicolas Le Cat, who proposed the use of mechanical equipment and liquids to demonstrate the functioning of the human body - breathing, circulation, digestion and the nervous system. In similar manner the Jacquet-Droz watchmakers used all kinds of materials, not least leather, cork and papier-mâché, in their automata and artificial limbs. While Madame du Coudray made her own midwifery 'machines' (although mere mannequins in truth, they were known as La Machine de Madame Du Coudray) from textiles and leather, sewing into them various wooden details, sponges and real pelvic bones.

Erasmus Darwin covered his own wooden 'speaking figure' in leather to make it more lifelike and if it spoke only a few words ('mother', 'father') it looked very real [12]. In contrast, Wolfgang von Kempelen, author of four 'speaking machines' (1778-1791) had no interest in making them lifelike, concentrating solely on the mechanisms of human speech. His Sprachmaschine could say the worlds 'Mutter' and 'Vater' in a childish voice, as well as simple phrase along the lines of 'you are my friend', 'I love you with all my heart' and 'let us go to Paris'. According to Goethe, von Kempelen's machine 'though not very eloquent, produces various childish words and intonations quite nicely, ${ }^{17}$.

In this sphere, the most successful were the tetes parlantes or 'speaking heads' of the Abbé Mical, presented to the Academy of Sciences in Paris in 1783. Made of copper, papier-mâché, parchment, leather and cork, they not only spoke but could engage in dialogue while actively gesticulating.

'First head: "The king brings peace to Europe."

Second head: "The peace crowns the king in glory."

16 'L'inspection de la machine fera mieux connoître l'imitation de la nature qu'un plus long détail,qui ressembleroit trop à une explication anatomique.' Jacques Vaucanson, Le mécanisme du flûteur automate, persenté à Messieurs de l'Académie Royale des Sciences, Paris: Jacques Guerin, 1738, p. 20.

17 'Kempelens Sprachmaschine, welche... zwar nicht sehr beredt ist, doch aber verschiedne kindische Worte und Töne ganz artig hervorbringt.' Letter from Johann Wolfgang Goethe to Carl August, Grand Duke of Saxe-Weimar-Eisenach, 12 June 1797. Available online: http://www.zeno.org/Literatur/M/Goethe,+Johann+Wolfgang/Briefe/1797.
First head: "And peace brings happiness to the people. Oh adored king, father of your peoples, their happiness shows Europe the glory of your throne.",

This praise of Louis XVI through the mouths of automata was an early example of the use of 'mathematical magic' for propaganda purposes.

In the novella Die Automate of 1814 by E. T. A. Hoffmann, a speaking head, which Hoffmann calls the Talking Turk, a clear reference to von Kempelen's chessplayer, on which see below, plays the role of oracle: '... the questioner asked in a whisper, leaning to the figure's right ear, and in reply the figure started to roll its eyes, turned its head to the questioner - one could even feel its breath (sic!), emerging from the figure's mouth — and truly from deep within the figure came the quiet answer.'

When thinking of particularly lifelike 'moving anatomies', particular interest is aroused by the wax figures used not only as teaching aids in medical schools but as curiosities for the educated public (as in the La Specola Cabinet of Physics and Natural History in Florence, which had anatomical models as well as botanical and mineral collections). Like the wooden anatomies that preceded them, wax anatomies were assembled from different parts and could be opened up (as if moving), allowing the viewer to see their insides. Real parts of the human body, such as bones and blood vessels (which were filled with tar) and such like, were often used in the making of wax anatomies in order to assert the authenticity of the figure. Yet it was the wax itself that was their main advantage: with wax, it was possible to capture the tint and texture of human skin; it could be painted and the colours retained their intensity ${ }^{18}$.

Such intense colours give the wax models unexpected vitality, a seemingly inappropriate effect that was further reinforced by the figures' theatrical poses and gestures (as with Clemente Susini's Venerina of 1780-1782 or AndréPierre Pinson's Seated Woman of the 1790s). We seem to see not anatomical models but living actresses, frozen in a pose.

Pinson's Woman with a Teardrop (1784) is a life-size anatomical model which can be opened and taken apart; even the brain can be removed. But why does her face show (express, even!) suffering? And why is she weeping? This is no mere anatomical teaching aid. For Pinson, who had several times applied - always unsuccessfully - to take part in the Salon in Paris (the Academy did not see wax figures as 'high' art), the tear must have played a quite specific role: serving as a reference to scenes of Lamentation, or perhaps the tears of Proserpine in Bernini's famous sculpture, it legitimised the wax anatomy as a kind of sculpture. Metaphorically of course, she weeps because she is 'alive'! And since that wax figure is 'alive', she can — like Schiller's phantasmagorical ghost, become the object of passion: in a novella by Champfleury, Diard, curator of a

18 Painted wax anatomies appeared at around the same time as tinted illustrations in anatomical tracts, which are thought to have been introduced by the anatomist and artist Jacques Fabien Gautier d'Agoty. Francesco Algarotti, Essai sur la peinture, Paris: Merlin, 1769, p. 21. 
collection of such figures, falls in love with one of them, Julie, and himself starts to turn into a wax figure ${ }^{19}$.

Anatomical figures, simulation of the human voice, of physiological processes and the internal organs, the mechanisms of automata and their lifelike quality all set down the direct route towards the idea of the artificial human, the cyborg. Which is just what was assembled by Dr Victor Frankenstein.

\section{ANDROID}

The fourth and most important source for Frankenstein's monster was the android, or the life-like automaton.

Androids first appeared in the context of that same doctrine of 'spreading faith' as had magic lanterns. The first depictions of both an android and a magic lantern appeared in one and the same manuscript, a codex by the Venetian engineer and 'magus' (as he described himself) Giovanni Fontana $^{20}$. Although largely devoted to military equipment, such as siege machines, Fontana's codex also includes illustrations of several other useful inventions. If Fontana's 'magic lantern' was intended to project an image of the devil onto a wall, his 'android' was like the devil himself (so perhaps it should more correctly be called a 'deviloid').

The first surviving androids, however, date from the sixteenth century. These small figures of monks, about 40 $\mathrm{cm}$ high, are made of wood and metal and contain a clock mechanism; the monks could walk, move their eyes and their lips as if in prayer, turn their heads and kiss the cross. It was perhaps such 'little automatory engines, that is to say, moving of themselves' that Gargantua made during rainy weather $^{21}$. (Rather like Byron and his friends writing horror stories in bad weather...)

But by the eighteenth century androids, like magic lanterns, had lost their magical force and moved into the sphere of science and the arts, becoming part of the world of entertainment ('teaching through entertainment'), a 'scientific toy'. According to Chamber's Cyclopedia, the 'Androide' was 'an automaton, in figure of a man, which by virtue of certain springs, \&c., duly contrived, walks, speaks, \&c' [13].

Over the course of the eighteenth century at least ten androids were made, many of them truly almost of a size with a human being. ${ }^{22}$ The most famous were the figures

19 Champfleury. 'L'homme aux figures de cire', published in the anthology Les excentriques, Paris: Michel Lévy fréres, 1852: 349-373. Diard's clothes hung off him as if off a wax figure, his eyes were glassy (wax figures, including Woman with a Teardrop, had eyes of glass or porcelain), and his skin took on a waxy yellowish tinge. At the end of the story Diard's wife relates how she found her husband in bed with Julie, after which Diard disappeared together with his wax beloved.

20 'Bellicorum instrumentorum liber cum figuris', 1420. Bayerische Staatsbibliothek, Munich, MS BSB Cod.icon. 242 Venice.

21 'Petits engins automates, c'est-à-dire soi mouvants eulxmesmes.' François Rabelais, Gargantua and his Son Pantagruel, Book 1, Chapter XXIV.

22 Vaucanson's Flute Player was $165 \mathrm{~cm}$ tall, Johann Friedrich Kaufmann's Trumpeter $170 \mathrm{~cm}$ and Jacquet-Droz's Girl Musician $137 \mathrm{~cm}$ playing the flute and the tambourine by Jacques de Vaucanson (1730s), the writing and drawing boys and girl musician by Pierre and Henri Jacquet-Droz (1774), Marie Antoinette by the cabinetmaker David Roentgen and the clockmaker Peter Kintzing (1785) and a trumpeter by the mechanic Johann Friedrich Kaufmann (1810). Lastly, of course, but by no means least, there was mechanic Wolfgang von Kempelen's quasi-android chess-playing Turk (1769), the most famous automaton of the eighteenth century. In fact it was infamous, thanks to the revelation of its scandalous deception: it became clear that the Turk was a fake, with a real human being, a professional chess-player, hiding beneath the table. Characteristically, von Kempelen was accused not only of being a charlatan but of magnetism and of being in touch with the devil.

Although androids were also 'a new kind of exhibition', they enjoyed less popularity than phantasmagorias, galvanic demonstrations or, particularly, balloon displays. (The figure of Marie Antoinette, for instance, was not shown to the wider public at all, being displayed only at court and then to the members of the Academy of Sciences, to which the queen gave it.) Even so, the educated public was well aware of their existence. Nearly all the androids then existing (as well as fictional ones, such as the 'digestive machine') were described in Jean Paul's novella 'Identities of the Man Served by Machines' (1789), about a collector of automata ${ }^{23}$. And the heroes of Hoffmann's Die Automate of 1814 saw nearly all the known eighteenth-century androids in the house of Professor X.

The most public showings were those of the automata of Jacquet-Droz. During the first demonstration at La Chauxde-Fonds in 1774, eyewitnesses recalled, despite the rain the street leading to the clockmaker's house was full of carriages and carts. Open from six in the morning until seven or eight in the evening [14], the exhibition included three androids and a Grotto filled with moving shepherds and shepherdesses playing music and dancing, with statues, fountains and even animals: a dog that barked, a cow with a suckling calf, goats clambering up a hill, and so on. It was shown in Paris in 1775 under the title Spectacle mécanique and went on to travel to London and then across Europe right into the 1780s.

Of all the Jacquet-Droz androids, which 'amazed all Paris' and 'left the city's artists in despair' ${ }^{24}$, the most famous was to be Girl at the Clavichord, a girl of ten or twelve years old that could move her shoulders, arms, hands, fingers, head and eyes and play several melodies, and to finish her performance (the clockwork mechanism could be wound to last an hour and a half!) she made an elegant curtsy. Viewers were amazed not only by the fact that the machine could play the clavichord but by the way the girl swayed in time to the music and rolled her eyes, how her breast heaved as if she were breathing: 'She is apparently agitated with an

23 J. P. F. Hasus (Jean Paul), 'Personalien vom Bedienten- und Maschinenmann', Auswahl aus des Teufels Papieren, [Gera,] 1789.

$24 \quad$ Louis Petit de Bachaumont, Mémoires secrets pour servir à l'histoire de la république des lettres en France depuis MDCCLXII jusqu'à nos jours, ou, Journal d'un observateur, VII: London, John Adamson, 1780, p. 273. 
anxiety and diffidence, not always felt in real life', wrote later one impressed observer, who saw Lady at her Pianoforte by Jacquet-Droz's pupil Henri Maillardet, inspired by Girl at the Clavichord [15]. During her performance, Jacquet-Droz's figure threw languishing looks first at her hands, then at the clavichord, and then at the spectators, her behaviour utterly in accord with current stereotypes of feminine virtue.

In other words, people were amazed by androids not only because they could simulate the movements of the human body, but because they expressed feelings and affects and simulated accepted contemporary gender and social practice $^{25}$.

But if androids simulated the behaviour of 'members of society', then they might in future actually become 'members of society'. Engineers certainly had such futurological intentions: within the new political and economic discourse, they saw androids as the ideal work force ('Ford's workers'). In the wake of the success of his androids, Vaucanson started to design automated looms for the silk factory at Lyon, which were intended to take the place of weavers (his project was not successful, however, since the weavers revolted), and Jeremy Bentham proposed the use of automata in the royal shipyards.

In parallel, androids, like wax figures, became the idealised objects of passion. In another story by Jean Paul, 'A Simple but Well-intentioned Biography of a Pleasant New Woman Made of Pure Wood that I Invented and Whom I Married' (1789), we read of how a woman is gradually brought to life, in a gender satire on woman's dumbness (i.e. lack of rights) and, in contraast, the garrulity (i.e. power) of von Kempelen Sprachmaschine ${ }^{26}$. In Hoffmann's Der Sandmann (1816) events take a tragic turn. Olympia, 'daughter' of Professor Spalanzani, is so lifelike that the hero Nathanael falls in love with her. But he goes mad when he sees her dismantled body. Spalanzani is then forced to flee in order to avoid criminal investigation 'for fraudulently introducing a machine into polite society ${ }^{27}$.

Like other scientific inventions in the eighteenth century, androids symbolised the victory of Reason over the forces of Nature; they were symbols of (proto) industrial modernity. At the same time, their very existence in the cultural context and the way they were perceived as 'scientific toys' whether stunning or frightening — brought androids back into the sphere of magic and mythology. Did not the philosophes compare Jacques de Vaucanson - inventor of the first androids, the machiniste, as Diderot called him in La rêve d'Alembert (1769) — with Prometheus: Voltaire called

25 On androids in the context of 'cultural scenarios' in the eighteenth century see: Adelheid Voskuhl, Androids in the Enlightenment. Mechanics, Artisans, and Cultures of the Self, Chicago-London: The University of Chicago Press, 2013.

26 J. P. F. Hasus (Jean Paul), 'Einfältige aber gutgemeinte Biographie einer neuen angenehmen Frau von bloßem Holz, die ich längst erfunden und geheirathet', Auswahl aus des Teufels Papieren, [Gera,] 1789.

$27 \quad$ 'Spalanzani mußte, wie gesagt, fort, um der

Kriminaluntersuchung wegen [des] der menschlichen Gesellschaft betrüglicherweise eingeschobenen Automats zu entgehen.' him 'the rival of Prometheus' in his sixth 'Discours en vers sur l'homme' of 1737; La Mettrie used the term 'the new Prometheus' in L'homme machine of 1748.

Prometheus is mentioned on the pages of François-Félix Nogaret's Mirror of Real Events (1790), in which a selftaught engineer who has created a flute-playing automaton (although he himself had never heard music) is endowed with a miraculous-magical gift of which Olympus might have been jealous, as the gods once were of Prometheus. This inventor was called Wak-wik-vauk-on-son-frankénsteïn, or simply Frankénsteïn, and that name says it all: it refers to Vaucanson and to Johann Conrad Delille in Frankenstein's castle, the alchemical creator of the elixir of life. And the syllable wik may have led Mary Shelley to choose the name Victor for her hero, the 'modern Prometheus' ${ }^{\text {, }}$.

\section{THE MODERN PROMETHEUS}

That same accusation that was made to Professor Spalanzani could be made to Dr Victor Frankenstein, that he 'fraudulently introduced a machine into polite society'. The being he had created escaped from his control, started to live an independent life and became a monster. Frankenstein had no desire to create a monster, dreaming rather of finding a way to 'banish disease from the human frame, and render man invulnerable to any but a violent death' (Frankenstein, Chapter I). That is, he dreamed of creating an ideal human. But the human became a monster [16]. Firstly because he was not like a man outwardly: extremely tall, he ran 'with more than mortal speed (Chapter VII) and was 'gigantic in stature, yet uncouth and distorted in its proportions' (Walton's Diary), and he was of an ugliness repeatedly emphasised through the book. Secondly, his behaviour unlike that of androids - did not meet social norms, did not fit into 'cultural scenarios': he became an avenger, a wretch, a murderer; he is often called a 'demon' or a 'devil'. Hence the monster could never become a 'member of society' and was doomed to loneliness.

When he met his creator the monster related the tale of how he started out on his independent, lonely life, and how he first discovered fire: 'I... was overcome with delight at the warmth I experienced from it. In my joy I thrust my hand into the live embers, but quickly drew it out again with a cry of pain. How strange, I though, that the same cause should produce such opposite effects! I examined the materials of the fire, and to my joy found it to be composed of wood. I quickly, collected some branches... When night came again, I found, with pleasure, that the fire gave light as well as heat;

28 We do not know if Shelley read Nogaret's tale. It is certainly not impossible, since he was a popular author and Le Miroir went through several editions. But no mention is made of Nogaret in Frankenstein. In any case, Shelley-Frankenstein's monster is the very opposite of NogaretFrankenstein's automaton, just as the genre of the Gothic novel was the antipode of the social allegory of which Nogaret's novella was representative. On Nogaret's short story and Mary Shelley's Frankenstein, see: Julia V. Douthwaite, with Daniel Richter, 'The Frankenstein of the French Revolution: Nogaret's Automaton Tale of 1790', European Romantic Review 20/3, 2009: 381-411; Julia V. Douthwaite, The Frankenstein of 1790 and Other Lost Chapters from Revolutionary France, Chicago-London: University of Chicago Press, 2012, pp. 59-97. 
and that the discovery of this element was useful to me in my food' (Chapter III).

The monster's tale unexpectedly echoes a fragment in the second book of Vitruvius, in which he speaks of 'the origins of mankind' and of a forest fire that first frightened people but then, 'when everything had calmed down, they came closer and noticed that the warmth from the flames was most pleasant, and they started to throw logs into the flames, thus maintaining it, inviting others to come and showing them its usefulness' (Ten Books on Architecture, II: I, 1). Through the invention of fire, according to Vitruvius, prehistoric people started to come together (the origins of society), to lay the bases of speech (the origins of language) and then started to build the first huts (the origins of architecture). Fire thus has a dual nature (which was immediately noticed by Frankenstein's monster): it is not only a destructive force but facilitates renewal and transformation of the world, allowing us to return to primordial simplicity and to natural humankind [17].

If we look at Frankenstein's creation not as an ideal but as an Original man, turned into a monster solely through his creator's technical errors when assembling his cyborg, the doctor does indeed look like a 'modern Prometheus', creating a man and giving him fire, and his errors are Zeus' punishments in Pandora's box.

It is no coincidence, of course, that Mary Shelley looked to the Promethean symbol and that the Age of Enlightenment repeatedly compared Jacques de Vaucanson with Prometheus. In the eighteenth century there was a reactivation - and a re-interpretation - of the image of Prometheus. As has been demonstrated by, among others, Alexey Losev [18] and Hans-Georg Gadamer, in the early modern age Prometheus was seen as the ideal artist, the anthropoplast sculptor moulding a human. In the words of Gadamer: 'In Prometheus, the creator of man, humanity now recognises its own power to create images in the realm of art. It is the myth of genius, the all-powerful productivity of art...,29

From the point of view of art's productive forces and its ability to transform the world (which Roland Barthes saw as the essence of all sorcery or magic [19]), it was a different Ancient hero who most appealed to eighteenth-century engineers: Daedalus, mythological inventor of automata, author of 'living' wooden statues which were so perfect that it seemed 'the image made by him was a being endowed with life' (Diodorus, Library of History, IV: 76, 2) and of Pasiphaë's cow, so lifelike that when she hid in it 'the bull came and coupled with it, as it if were a real cow' (Apollodorus, Library, III: 1, 4).

\footnotetext{
29 'In dem Menschenbildner Prometheus erkennt sich nun die Menschheit in ihrer eigenen bildnerischen Macht im Reiche der Kunst. Es ist der Mythos des Genies, der allmächtigen Produktivität des

Künstlertums...' Hans-Georg Gadamer, 'Prometheus und die Tragödie der Kultur' (1946), in: Festschrift: Rudolf Bultmann zum 65. Geburtstag, Stuttgart-Cologne: Kohlhammer Verlag, 1949, pp. 74-83.
}

\section{CONCLUSION}

Daedaleus (aka Vaucanson, aka Aldini, aka Robertson, aka Frankenstein) is the artist-demiurge, whose art combines Platonic concepts of craft (techne) and poetry (poiesis). As a demiurge, Daedalus had a mastery of the magic reserved for the gods: when they saw Daedalus and Icarus flying, the 'astonished might observe them on the wing, and worship them as gods' (Ovid, Metamorphoses, VIII: 217-220). Like the gods he was able to change the world order (the Labyrinth itself being a metaphor for such an altered world order), perform magical actions (such as flying) and create miraculous objects (such as his living statues). He was invested not only with deftness of hand but could 'turn his mind to arts unknown' (Ovid, Metamorphses, VIII: 189) [20].

Which brings ups back to Mary Shelley's description of those scientists who 'have indeed performed miracles. They penetrate into the recesses of nature, and show how she works in her hiding places. They ascend into the heavens: they have discovered how the blood circulates, and the nature of the air we breathe. They have acquired new and almost unlimited powers.'

\section{REFERENCES}

[1] Barbara Stafford. Body Criticism. Imaging the Unseen in Enlightenment Art and Medicine, Cambridge, MA-London: The MIT Press, 1994: 66.

[2] Purinton: Marjean D. Purinton. 'Science Fiction and Techno-Gothic Drama: Romantic Playwrights Joanna Baillie and Jane Scott', Romanticism on the Net 21, 2001. Available online: http://www.erudit.org/revue/ron/2001/v/n21/005968ar.html.

[3] Ephraim Chambers. Cyclopaedia, 2 vols, London: Knapton, Darby etc, 1728, II: 481 - 'Magic: Magic Lanthorn'.

[4] Stefan Andriopoulos. Ghostly Apparitions. German Idealism, the Gothic Novel, and Optical Media, New York: Zone Books, 2013, p. 36.

[5] Ibid. p. 33.

[6] 'phantasmagorical repertoire': Robertson, Op. cit., I, $272 \mathrm{ff}$.

[7] David Brewster. Letters on Natural Magic, addressed to Sir Walter Scott, first published 1832, 5th edn, London: John Murray, 1842, p. 82.

[8] Robertson. Op. cit., I: 215-221.

[9] Giovanni [Jean] Aldini. Theoretical and Experimental Essay on Galvanism, Paris: Fournier fils, 1804, I, p. 122.

[10] The Newgate Calendar, 18 January 1803. Available online: http://www.exclassics.com/newgate/ng464.htm.

[11] Michel Foucault, Surveiller et punir. Naissance de la prison, Paris: Gallimard, 1975, English translation Discipline and Punish: The Birth of the Prison, London: Pantheon, 1977, re-issued New York: Vintage Books, 1995

[12] Darwin. The Temple of Nature; or, The Origin of Society, London: J. Johnson, 1803. Additional Notes, pp. 119-120.

[13] Chambers. Op. cit., I: 87.

[14] Adelheid Voskuhl. Androids in the Enlightenment. Mechanics, Artisans, and Cultures of the Self, Chicago-London: The University of Chicago Press, 2013: $64 \mathrm{ff}$.

[15] The New Monthly Magazine and Literary Journal, I, London: Henry Colburn and Co.,1821: 531 .

[16] Maienschein, Kate Maccord. 'Changing Conceptions of Human Nature', in: David H. Guston et al, Frankenstein... Annotated for Scientists, Engineers, and Creators of All Kinds, Cambridge, MALondon: The MIT Press, 2017, pp. 215-221. 
[17] O. V. Medvedkova. 'In the Beginning, There was Fire: Vitruvius and the Origin of the City', in: Marco Folin, Monica Preti, eds, Wounded Cities: The Representation of Urban Disasters in European Art (14th20th Centuries), Leiden: Brill, 2015, pp. 75-99.

[18] A. F. Losev. Historical Specificity of the Symbol. The International Image of Prometheus, in Russian Chapter VII of The Question of Symbol and Realist Art, in Russian Moscow, 1976. Available online: http://www.gumer.info/bibliotek_Buks/Culture/Los_PrSimv/07.php.

[19] Roland Barthes. Mythologies, tr. Annette Lavers, New York: Noonday Press, 1972, pp. 97-99.

[20] Nikolai Molok. The Flying Architect. Daedalus and Amphion in the Eighteenth Century, Iskusstvoznanie, 2, 2017, pp. 42-83. 